\title{
Dramaturgical Analysis of Vlogger's Impression Management on Social Media
}

\author{
Ester Krisnawati ${ }^{1, a)}$ \\ ${ }^{1}$ Universitas Kristen Satya Wacana, Salatiga, Indonesia \\ a)author correspondence : ester.krisnawati@uksw.edu
}

DOI: https://doi.org/10.18196/ikm.121035

Article Info

Article history:

Received 16 Mar 2020

Revised 08 Apr 2020

Accepted 5 May 2020

\section{ABSTRACT}

The presence of social media is not only used by someone to communicate with other people but also to present oneself with certain goals. The appearance of celebgram and vloggers has shown that social media is a place to show oneself in front of others. This study aims to describe the impression management vlogger in the "Kumit Project" account on social media by using a dramaturgy approach. The observation units in this study were the Kumit Project's accounts on Instagram and Youtube. This qualitative descriptive study used the Erving Goffman dramaturgical analysis approach. The results showed that when on the front stage, Kumit Project, through its actors Madkucil and Cimit, performed impression management to create an impression on their audience. While on the back stage, Kumit Project was a team with the actors Madkucil and Cimit, whom the relationship as lovers was portrayed as the front stage. The drama that they played on the front stage is a real picture like the one on the back with additional background settings to add to the dramatization.

Keywords: Dramaturgy; Impression management; Instagram; Youtube

\section{ABSTRAK}

Kehadiran media sosial tidak hanya dimanfaatkan seseorang untuk sarana berkomunikasi dengan orang lain, namun media sosial sekarang ini banyak digunakan untuk menampilkan diri seseorang dengan tujuan-tujuan tertentu. Munculnya selebgram dan vlogger menunjukkan bahwa media sosial menjadi ajang untuk menunjukkan diri seseorang di hadapan orang lain. Penelitian ini bertujuan untuk menggambarkan Impression Management Vlogger dalam akun "Kumit Project" di media sosial dengan pendekatan dramaturgi. Unit amatan dalam penelitian ini yaitu akun Kumit Project di Instagram dan Youtube. Jenis penelitian ini adalah penelitian deskriptif kualitatif menggunakan pendekatan analisis dramaturgi Erving Goffman. Hasil penelitian menunjukkan bahwa ketika di panggung depan, Kumit Project melalui aktornya Madkucil dan Cimit melakukan impression management untuk menciptakan kesan di mata penontonnya. Sedangkan gambaran panggung belakang Kumit Project mereka adalah tim dengan aktor Madkucil dan Cimit yang mempunyai relasi sebagai sepasang kekasih dengan gaya pacaran yang tergambarkan seperti dipanggung depan. Dramaturgi yang mereka mainkan di panggung depan merupakan gambaran sesungguhnya seperti yang ada di panggung belakang dengan penambahan setting latar untuk menambah dramatisasi.

Keywords: Dramaturgi; Impression management; Instagram; Youtube. 


\section{INTRODUCTION}

Human behavior in the digital era is entangled with social media use. Social media has affected people's behavior and communication without notice, making checking social media accounts healthy to gain new information about one's surroundings. Social media allays rudimentary human needs to interact with other human beings. It is not surprising since Van Dijk in Fuchs (2014:35-36) observed that social media is a platform that facilitates the users to have an activity or collaboration that focuses on the existence of the users. Social media, thus, is a connecting medium among the users and a place to socialize with other users. Uniquely, as stated by Rulli (2015: 11), social media is a medium fabricated from the internet network, and it can not only represent the users but also help each user to interact, share information, collaborate and communicate, enabling virtual social cohesion. Concerning its development, social media consisted of 6 categories (Rulli, 2015:39), namely (1) social network media, e.g., Facebook, Instagram, Path, (2) online journal/ blog, (3) microblogging, e.g., Twitter, (4) sharing media, e.g., Youtube, (5) social marker, e.g., delicious.com, and (6) shared content media, e.g., Wiki.

Social media development continually follows human needs. For example, when society called for a medium that can share pictures with other people, Kevin Systrom and Mike Krieger in 2010 , created a new social media platform called Instagram. Instagram aimed to help the users to share pictures and short duration videos (less than one minute) with unique supporting features. In addition to sharing pictures and videos, Instagram users can also give comments or captions, likes, and hashtags, as well as creating a social system by being followers or following other users. Besides Instagram, another platform that can be used to upload video, and even with a longer duration, is Youtube. Youtube is a social media platform that, apart from being under the category of sharing media, figures in assisting the users to search for information and entertainment. It can also be useful for watching lives and shares videos only with one platform. Youtube was initiated by Chad Hurley, Steve Chen, and Jawed Karim, former employees of Paypal. Youtube started to launch in mid-2015. Through Instagram and Youtube, people try to show themselves as compelling as possible to attract other's attention.

Recently, social media has not been foreign anymore; they have been accepted as a new culture out of its capability of having virtual interaction without face-to-face communication. This feature makes social media a medium of presentation and self-actualization. It provides a sphere to develop oneself by creating works that latter can be his branding. In this vein, People often scrutiny images that they are about to show to other people, whether in real or virtual life. In this context, an image that one shows resemble actors that act on the stage. On the stage, the actor tries to show a particular image to impress his audiences. The actor manages verbal and non-verbal language properly that image he wishes to transmit emerge as intended. After successfully creating the image he longs for, he may be valued positively and, to some extent, earn material benefits. For amplifying the effect, the actor should consider setting (location), and dress code (what is worn), word choices as supporting caption. A caption is vital to leave a positive impression on other people and reach the planned goal. Goffman called this attraction management, i.e., impression management in performing dramaturgy.

Impression management is a method to present oneself. It is an action to show oneself by creating a specific impression in front of other people by managing attitude and behavior. The aim is to produce a particular impression on other people and enable other people to interpret the identity created. Thus, impression management is simply an attempt to present oneself to other people. Adding to this, Mulyana (2008: 112) stated that self-presentation grows a specific impression in other people by organizing his behavior so that other people can interpret his identity as what he intends.

Goffman supposed one's life as a theater stage. It is copious with drama and equipped with stage setting. The actor of life is anyone. Principally, a dramaturgy supposed front and back-stage. On the front-stage, there are settings, leading personal, expressive equipment (tools for self-expressing), while the back-stage is the place of the self itself (all hidden activities to ensure the success of action in the front stage). In dramaturgy theory, each individual or actor would act, whether intentionally or unintentionally, to represent himself and aims to create a particular impression. Another aim of impression management is to create a perspective that can fit with what actors plan to show on the dramaturgy stage. Impression management is performed when someone is interacting with other people by organizing impression in a planned setting to create a specific impression on the people that are asked to interact. These whole aspects are what is presented in a dramaturgy (Goffman, 1956:8). 
Jones \& Pittman (1982) created a system to record any impression management behaviors. In the impression management process, a person should have a strategy of identifying construction in front of many people. The strategy that was done in impression management is self-promotion, ingratiation, intimidation, exemplification, and supplication.

The research focuses on dramaturgy on social media, primarily on Instagram and Youtube. The researcher sees, as Goffman's theory of dramaturgy, that an image showed on social media does not always represent the personality of the person in question. It was similar to Sabrina Paulina's research (2017) titled "Social media as Self Presentation Page of Mordelente." The research showed that what is showed on Mordelente Itil's Youtube account is the real expectation of the account owner. On the front stage, Mordelente Itil often talks about forbidden topics. However, Modelente Itil is more expressive in terms of thinking, behaving, and uttering on the Internet than in real life (back stage). Mordelente Itil stands for homosexuality issues and holds that sexuality is a part of its campaign for supporting its existence. He assumes that what he shows on social media is unproblematic. It implies that he believes that social media is a stage that provides a deliberate sphere for users to express themselves.

After considering the result of previous research on the same topic, the researcher decided to analyze the Kumit Project's Youtube and Instagram account. The research, with a dramaturgical approach, discerned how Kumit Project performed impression management on social media to create a specific impression. The research aims to understand how Kumit Project creates impressions through dramaturgy on social media, as well as their front and back stage.

\section{METHODS}

The research used a qualitative descriptive method. The units of analysis were the dramaturgy played by Kumit Project through impression management on their Instagram's and Youtube's account, while the units of observation were the videos uploaded on their accounts. The primary data were data gained directly from object investigated, namely Kumit Project, while secondary data were data obtained from individual institutions, such as books and literature. The data were collected through two methods: observation and literature study. The researcher observed videos and pictures uploaded on Instagram and Youtube account of Kumit Project and analyzed books and journals concerning the topics in question. The researcher validated the research using data triangulation by interviewing Madkucil and Cimit online.

\section{RESULT AND DISCUSSION}

\section{Kumit Project's Activity on Social Media}

Kumit Project is an account on Instagram and Youtube, owned by Madkucil and Cimit. Madkucil is the alias of Rahmat Hidayat, while Matkucil is the alias of Fitria H. Agustina. Before creating the account of Kumit Project, Madkucil and Cimit had been known as celebgrams (celebrity endorsers) and influencers. The appellation of their Instagram and Youtube accounts, namely the Kumit Project, stems from their name. Ku stems from Madkucil while Mit was from Cimit. The project itself is a collective term for work done by a team. The last term is what makes Kumit Project is not occupied solely by Madkucil and Cimit, but also by a team that helps the production process. The followings are the appearance of the home of Kumit Project's accounts on Instagram and Youtube.



Figure 1. Kumit Project's accounts on Youtube and Instagram (source: Kumit Project's home on Youtube Channel and Instagram, May 2019) 
At first, Kumit Project only had an Instagram account, and the name is "Kumit Project Official." The account currently has 122.000 followers. 1-minute limitation on Instagram got the Kumit Project shifted to Youtube Channel, making their Instagram post only as of the trailer of their Youtube video, while the full videos were uploaded on the Youtube channel. As regards this, Madkucil said that "we created Youtube Channel to explore our works and improve the quality." The reason is that Instagram only limited to 1-minute, while Youtube can post a video that is more than 1-minute. Furthermore, it is also useful to make you closer to us and importantly satisfied watching."

The Youtube channel of the Kumit Project started on January 17, 2017. When this present article was written, the number of subscribers had amounted to 690.594 subscribers. Furthermore, their video had been watched for more than 98.037.351 times on April 4, 2020. The followings are some video contents in Kumit Project's Youtube channel:

- Daily Vlog: the videos show the daily activity of Madkucil and Cimit without setting.

- Sketch Comedy: it is a new project of Kumit Project, and talks about a series story with comedy concept. The name of the series is "Datang Duduk Pulang Ganteng" (Arriving Sitting Leaving Handsome) or DDPG.

- Kumit Q\&A: it is content on Youtube Channel that was uploaded on Instagram account. It comprises questions and answers concerning Kumit Project and the actors.

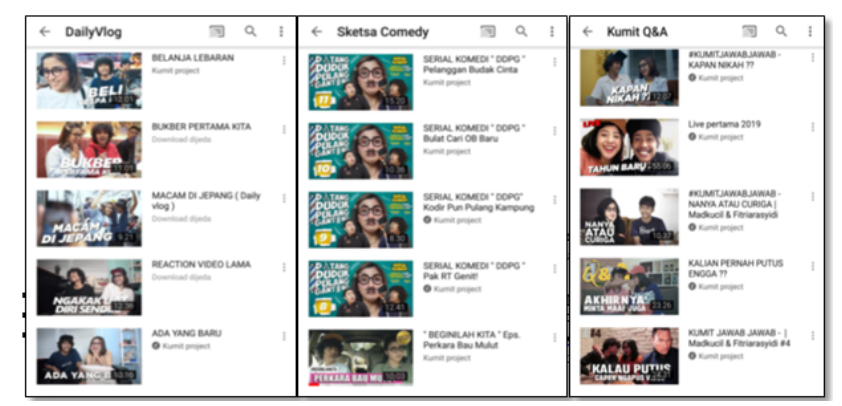

Figure 2. The playlist of the video content of Kumit Project's Youtube Channel (source: the Kumit Project's home one Youtube Channel and Instagram, May 2019)

- Vlog Travelling: it is traveling videos of the Kumit Project to several tourism destinations.

- Beginilah Kita (This is how we are): it is a video content that shows the love story of Madkucil and Cimit.

- Kumit BBC: it is video content that consists of the stories of the followers of Kumit Project. The story is sent from DM (Direct Message of the Kumit Project's Instagram account. Madkucil and Cimit read the story.



Figure 3. Playlist of Kumit Project's channel on Youtube

(source: of the Kumit Project's home one Youtube Channel and Instagram, May 2019)

Post on the Kumit Project's Instagram account is similar to videos uploaded on their Youtube, but the duration is less than one minute. Therefore, concerning the video, Instagram videos are not different from videos on their Youtube. Besides videos, Kumit Projects also posts pictures and posters for the promotions of their short movie. Sometimes, the pictures also promoted their vlogs on Kumit 
Project's Youtube Channel. For instance, a comedy series titled “Arriving Sitting Scissor Island" that was uploaded on Youtube Channel was promoted though Kumit Project's Instagram. About the relationship with the followers, through Kumit Project's Instagram account, Madkucil and Cimit ask their followers to send their interesting stories regarding love, work, friendship, or horror to Kumit Project's direct message account. The stories then are read by Madkucil and Cimit in the video "Kumit BBC" that was uploaded on Kumit Project's Youtube channel. Through his Instagram, too, the Kumit project creates giveaway events for their followers with a compelling prize, such as cell phone. The followings are some pictures of videos on Kumit Project's Instagram:

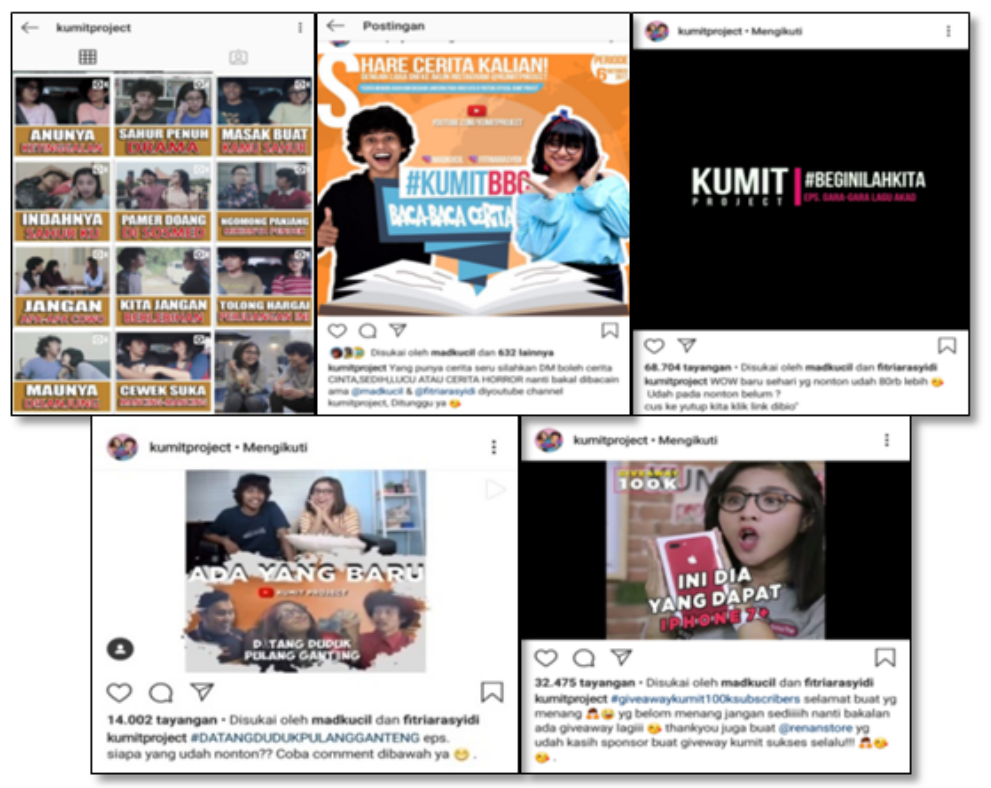

Figure 4. Some posts on Kumit Project's Instagram

(source: the Kumit Project's home one Youtube Channel and Instagram (May 2019)

\section{Kumit Project's Impression Managemen on Instagram and Youtube}

The characteristics of Dramaturgy, according to Goffman, is impression management, i.e., the way a person shows himself in front of people, including consistency in playing his role and attempts in persuading other people to have a specific impression. The followings are the explanation of impression management strategy performed on Kumit Project's account on Instagram and Youtube.

\section{Development of self-promotion}

This strategy aims to perform competence or expertise in some fields so that people can be impressed. The core of self-promotion is to make a quality prominent, such as achievement, qualification, or self-advertisement, and to show the positive side of the actor. Through Kumit Project, the actors and creative teams demonstrated their works by making videos and uploading them on Instagram and Youtube. The content of the videos on the Kumit Project was intended to show that, in creating the works, the Kumit Project did it well, as if they want to show that those videos were not unplanned vlogs. Instead, for them, it was well-designed vlogs. It was edited and set professionally. Acting performed by the actors was also natural and not awkward, not to mention that they appreciated their roles, probably because they were a couple in the first place, and it made them more comfortable to play their roles on the videos. In attracting audiences' attention, Madkucil featured characteristics of being loyal, responsible, yielding, and benevolent. On the other hand, Cimit featured characters of being emotional, accepting the couple as it is, loyal, bossy, and spoiled. She also often used make-up and costume.

2. Kumit Project's strategy to gain attention from social media users (ingratiation)

The strategy aims to attract people's attention through positive activity or other things that give positive values for other people. Kumit Project videos showed complicated scenes, ranging from 
disagreement, quarrel, jealousy, romanticism, care, to indifference. All this was intended to get the attention of their followers and subscribers. Some of the scenes showed Cimit being irritated, garrulous, and egoistic, while Madkucil was pictured yielding and often accused by Cimit. All the drama was often started from a debate between Madkucil and Cimit concerning a topic, and it ended with either one of them surrendered or a romantic side appear. The focus was Madkucil was loyal, and Cimit was upsetting, but both of them were shown easy-going and thoughtful. Furthermore, Madkucil's or Cimit's humorous character often made the audiences laughing when they were watching the videos. The characters were shown on their videos, and it was Kumit Project's method to attract the attention of their followers and subscribers.

\section{Emotional (intimidation)}

This strategy is often put at work to acquire power. The main characteristic is threatening, anger statement, and hostility towards something. Intimidation on Kumit Project's videos was performed by Cimit that often rebuked Madkucil. In some videos, Cimit looked rebuking Madkucil merely because he mentioned his former girlfriend. Furthermore, there was a time when Madkucil was blamed as he was late in picking up Cimit. In the videos mentioned, Cimit often looked more prominent and preponderance than Madkucil. Cimit's character in each video invariably intimidated Madkucil, but it was the attractive point of the Kumit Project. The intimidation strategy succeeded in attracting heed from the audiences.

\section{Description of the actor self-presentation (Exemplification)}

This strategy attempts to make people believe that the actor has a high moral standard or superior in terms of morals. Kumit project's works talked about the relationship between Madkucil and Cimit as a couple, and it was colored with fights, disagreements, jealousy, and romanticism. Through the video uploaded on social media, Madkucil and Cimit seemed to show themselves genuinely. Cimit's character demonstrated that she is a girl with high-level discipline, not forget to mention her well-arranged life. It seemed that everything perfect. By contrast, Madkucil, that was more indifferent, was less discipline; he was often late in picking up Cimit. However, Madkucil's positive attitude is that he voluntarily did anything to Cimit (self-sacrifice). Therefore, in terms of concern and thoughtfulness, Madkucil was more concerned with his sacrifice. Contents on the videos showed the natural life of being a couple. They accepted each other lack, respecting differences, and willing to sacrifice. The latest was performed by willing to surrender for the sake of the relationship.

\section{Begging for pity (Supplication)}

This strategy tries to make the actor powerless so that the audience will provide succor to the actor. On Kumit Project's accounts, both on Instagram or Youtube, supplication was not found. When a plot told a story about Madkucil that was cornered or scolded by Cimit, the comments of the followers and subscribers tended to say the plot was hilarious and comical. Indeed, some of them laughed at it. The expressions that were shown by Madkucil or Cimit when they were sad or under-pressured made the followers pleased and gave positive value towards the video. The attention gained by the Kumit Project was not from the powerless actors but the nature of the videos that was exciting so that people watched it. The researcher did not find a supplication strategy in the videos that showed the powerlessness of the actors.

Erving Goffman assumed that when someone interacts with other people, the communicator will present a self-image that will be received by the communicant. Through Kumit Project, the actors applied five strategies of impression management techniques to create a specific impression and achieve a certain target. The impression management was designed in a script before played by the Kumit Project's actors. The analysis above has shown how Madkucil and Cimit created a certain impression on the audiences. They wanted to show that, as video creators, they were capable of making hilarious, engaging, and simple movies, as well as a movie that described problems faced by the younger generation when they have a relationship. Madkucil's and Cimit's characters were described well, and importantly their roles were not different from their real character.

Impression management asserts that each individual or group should decide and nurture the impression that is per the perception of other people that become the target. Impression management requires consistency to play the role and persuade the audience so that the audience can perform an 
action that is desired by the actor. Kumit Project's video on Instagram and Youtube looked consistent with its contents. The stories always focus on problems relating to couples, the former couple, and jealousy, or in short, young romance. The consistency of the Kumit Project can also be seen from the character and role that was played by each actor.

\section{Kumit Project in Dramaturgical Analysis}

Kumit Project's dramaturgy on social media was analyzed from the context of the behavior of the Kumit Project in achieving its goals and from the results of the behaviors. Dramaturgy assumes that in the interaction between actors and followers, there exists an agreed behavior that can guide the social interaction to the aim intended. The evidence of the role play on the Kumit Project's account can be seen from the front and back stage.

\section{Kumit Project as the front stage}

The front stage is a part of the show functioning as a place in which the audiences can define the behavior of the actors. On the front stage, the actors fit the situation with the audience. That is the reason for the setting that helps the play of the actor maximally. Kumit Project's account was the front stage of the actors and the crew involved. The account was the place for them to be creative in making videos. It is per Goffman's thought (Poloma, 2003:232) that each individual needs a place and attribute to be able to play roles. That is, the account was used by some people to channel their creativity, ideas, and thought in videos that eventually uploaded to social media, including Madkucil and Cimit expressing themselves on the videos. Generally, seeing from the content of the videos, Kumit planned to show how the relationship of the current younger generation is inseparable from issues regarding the former couple, material possesions, to readiness to embrace the rituals and the life of marriage. It was then covered in a commonplace and straightforward dialogue.

On the front stage, there are setting and personal front. The setting, in this case, is related to tools arrangement used to maximize the appearance at the front page. Kumit Project often chose a car, living room, and dining room, as the setting of the location. The tools that were often used were cell phones, television remote, and laptop. Those three tools were the most used by Madkucil or Cimit when they are having a dialogue on the video.

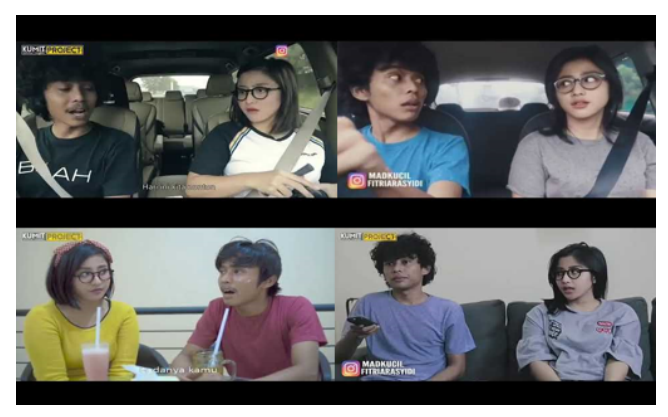

Figure 5. The setting of the shooting location of Kumit Project's Video

(source: the Kumit Project's home one Youtube Channel and Instagram, May 2019)

Personal front of the Kumit Project included self-presentation in the forms of verbal and nonverbal (body language) language played by Madkucil and Cimit. In Kumit Project's videos, Cimit was talkative, bossy, blunt, and irritable. Anything did by Madkucil always triggered Cimit to be irritated with her high and fast intonation. It was different from Madkucil that was calmer, although he also was witnessed talking with a high tone to Cimit every time he had lost his temper to Cimit's attitude. Madkucil and Cimit were well-expressed when they were irritated, sad, upset, and even, also, happy. The body gestures that were often shown were driving a car or holding a phone when they were talking. Their typical dress attributes were a t-shirt and cell phone for Madkucil and glasses, a t-shirt, and makeup for Cimit.

Through the front page, Kumit Project presented a couple that run their relationship naturally, which sometimes colored by fight, jealousy, and even sometimes egoism. Although they did not exploit the romance side very much, they seemed to enjoy witnessing their relationship time. 
Understandable and straightforward use of language, combining with their interesting expression, made the audiences follow their news videos uploaded on Kumit Project's account. Topics chosen on the videos were the issues that were also faced by current younger couples, making the topics easier to deliver to the audiences. In general, Kumit Project was the front stage of a group, and they used social media to show the self-existence of Kumit Project's members.

Another aspect of the front page is that the actors tried to convey the impression that they have a unique interaction or close social distance with the audiences than the real social distance. It can be seen on the Kumit Project's attempt to be closer to the followers, namely by making video content titled "Kumit Q\&A and Kumit BBC." Through those two vide contents, Kumit Projects interacted with their followers and subscribers. Kumit Project provided an opportunity to the followers and subscribers to ask a question about Madkucil and Cimit and share their unique relationship to be read in the Kumit BBC. The social distance that was established by Kumit Project create a positive impression on the followers and subscribers that Kumit Project was friendly. This social distance was established with not only video content but also through the appearance of the role of Kumit Project's actor. For example, Madkucil's roles that often witnessed dominated, not egoistic, sad, irritable, trigger the audience to sympathize, and empathize with him, and it can be seen from the comment sections.

Various contents uploaded on Instagram and Youtube can trigger the followers and subscribers to obtain the image the actors live and follow the plot presented by the Kumit Project. The audience was led to feel what was happening in the actor's mind. Also, the actor was made emotional, upset, and even laughed, watching the role of the actor on the stage of the Kumit Project. Comment and questions performed by the audiences signified that Kumit Project was successful in dragging audiences to belive and receive messages conveyed by Kumit Project.

\section{Kumit Project as the Back Stage}

The back stage is the situation where the actor faces no audience so that the actor can act deliberately without paying attention to their behavior that is usually played. The back stage also conceals how the daily life of the actor that is rarely or even never shown to the front stage (in this case, social media). Typically, the personal character on the back stage was different from the character on the front page. On the back stage, the actor can also prepare anything that would be used on the front stage.

The back stage cannot be seen from the account of Instagram and Youtube of the Kumit Project. The back stage was the stage outside the regular stage of Kumit Project. The back stage was the actors' and crew's real life and the preparation time before heading to the front stage. The back stage was the real life of Madkucil and Cimit. It was their personal lives and their daily activities when they are not on the stage of Kumit Project. The role-play of Kumit Project's actors, Madkucil and Cimit, was not different from their real character in their real lives. Soo to the appearance of the actors and their way of talking. Their relationship with the videos and real-life was similar too. It is not surprising since most of the source of the story was based on their daily lives and try to describe today's young couple issues. From this back stage the real-life of Madkucil and Cimit was polished with a scenario, professional shooting, and editing before uploaded on Kumit Project's social media account, Madkucil's and Fitriarasyidi's account.

Besides the real life of the actors, the back stage also included the preparatory stage, namely scenario/script stage, technical stage, and preparatory time for the actors itself to play their roles. Kumit Project, of course, prepared their videos so that their front page looked immaculate and entertaining for the followers. As video creators, Kumit Project used professional shooting equipment, ranging from camera, tripod, lighting, audio, laptop, to mini studio. Also, Kumit Project had crews or teams that produce their videos. Madkucil itself was both director and producer from Kumit Project. 




Figure 6. Indoor Mini Studio of Kumit Project (source: https://www.instagram.com/p/BZygHXcja0m/)

Differences in roles at the back and front stage lies on the dramatization. On the front page, most of the scenes resulted from dramatization while on the back stage each actor has its own business and jobs. When Madkucil and Cimit met personally, they seemed an average couple. Madkucil and Cimit had their social media accounts; Madkucil focused on being a vlogger, Cimit was more into being an influencer. The back stage was filled by individuals that were passionate about showing their creativity and doing works that can be seen by other people and entertained them. It was on the back stage Kumit Project's member prepared all needed that related to audio and visual to support the short drama show of Madkucil and Cimit.

\section{Dramaturgical Analysis of Kumit Project's Impression Management}

Audiences, whether personal or collective, use social media to bolster their existence as social beings. Nurudin (2015) contended that it applies not only to one's relationship to other individuals but also to the social environment by being a place to show the outcome of what they think, feel, and do in the forms of work. Nurudin believed that social media present two worlds, namely real and virtual, and it can produce two different sides of a thing. For example, while someone can be vocal in the virtual world, they can be just average in the real world. It showed that someone might be a different character on the front stage (virtual world), as opposed to his back stage character (real world).

Dramaturgy theory developed by Erving Goffman explained that identity is presented to audiences in a certain event and time. Dramaturgy is a process where a communicator plays a role in front of an audience. This theory describes a show of some people that are not based on their real characters. Rather, as well as maximizing the roles he has at the time, they based their character on the existing situation. In this case, the communicator's role is to make an image with the help of a script, and the message should make the audience believe in what is presented by the communicator. Besides, dramaturgy's theory is also used by Erving Goffman to compare humans in real life and on stage. This is the reason for which the researchers used a dramaturgical approach to analyze how communicator presents themselves through their roles on the stage, which in this is Kumit Project on social media. Besides, this research analyzed the use of symbols to achieve their goals and differences in communicators' life and their roles on the Kumit Project's stage. Therefore, in dramaturgy, the communicator became another person, the person that he played aims to find out how the audience evaluates the character they play.

Mulyana (2004: 123) explained that Goffman's focus on dramaturgy is not only about individuals but also to the group. In a group, apart from showing the roles and character individually, social actors also manage impressions towards other people so that other people give a certain evaluation toward the group. It is usually called team performance in which the group dramatizes an activity they play. In this context, teamwork is a necessity to create and keep team performance on the front stage. The group should prepare everything necessary for the show, coupled with well-planning, to ensure the show runs smoothly. As Kumit Project preparing the script and set to play on the front stage, each 
person that becomes an actor on his social media accounts also performs the same thing. The account owner prepares the type of post he wishes to show in his social media.

Impression management is a technique or method used by actors to alter their looks and character fitting with the setting. Through impression management, an actor should manage their selfpresentation to develop an audience response towards his presentation. Impression management referred to an image that is presented by the actors when they play their roles. In a dramaturgy, on the front page, the actor would do impression management by making other people that watch the actor elicit a certain impression about the actor. On the front stage, someone as an actor performs some activities, such as promoting himself and searching for the attention of other people, but they also hope for some outcomes, such as considered having promising quality, power, and emphatic when the actor is powerless.

Furthermore, impression management also explains that when humans interact with each other, they try to present their self-image that would be received by the communicant. Impression management is then used by the actor to build a particular impression in a particular situation for a particular goal. Impression management is often performed by social media account in attracting other's heed. That is, everyone, without doubt, prepares what they would present on their social media account, ranging from text, pictures, to videos. Furthermore, other people that look at the post are persuaded to believe and produce a certain impression on the person. This is a dramaturgy game in which all people must perform it, intentionally or not.

The dramaturgy of the Kumit Project is what is presented on the front and back stage of the Kumit Project. On the back stage, there were only actors, namely Madkucil and Fitira (Cimit), with their personal lives, although they were a couple. Of course, in reality, Madkucil's and Fitira's lives were shown only on the back stage. In other words, no audience comprehended the secret fully behind their personal lives, including conflicts and relationships within it and relations with other people, such as family. By contrast, Madkucil and Fitria used Kumit Project as their front stage to channel their creative ideas, which was based on their relationship story and other common young generation issues in the relationship. Fitira's role as Cimit, who was dominant, and Madkucil, who tended to less egoistic, was one of the realizations. Although on the front page, Kumit Project often presented stories about Madkucil's and Cimit's relationships, they did not show their daily lives as their work, family, and study. What was presented was their relationship story. The dramaturgy was clearly seen from the roles of Madkucil and Cimit on the Kumit Project's stage. Therefore, dramaturgy is used to analyze the front and back stage of the Kumit Project.

Through this research, impression management strategy was used to analyze how dramaturgy played by actors through front stages, namely, Kumit Project's Instagram and Youtube account were capable of stirring a positive impression on the audiences. At the front page, the actors were capable of describing their character so that impression about having a relationship can be planted well. On the back stage, by contrast, the characters of the actors were not really different. It made the actors more flexible to play on the stage since it seems, they presented their normal activities on the back stage. The only difference is that on the front stage, all elements had been set so that it looked more dramatic and emotional to watch. A dramatization was often set by the account owners when they were on the front page (social media). They made them with the help of the setting that aimed to convince the audience about the actors. With dramatization and setting, the audiences will be more convinced that what was presented on the front stage was similar to the back stage reality. For example, a person that purchase a big-ticket item at the supermarket and uploads it on the internet would give the impression that the person is wealthy. The reason is that they purchase a big-ticket item, although in real life it is still indefinite.

Social media, in the end, is used as a dramaturgy stage by the account owners as a means to present themselves and play their roles on the stage. The account owners would try to control themselves in terms of looks, body, behavior when they play their roles on social media. On the front page, namely on social media, someone can polish as beautiful as they can and act as promising as they can to look immaculate, while the audiences cannot see the reality of the account owners (the back stage). The account owners became actors and play their roles as promising as they can to ensure that other people follow them and have the impression that fits with the account intention. Many social media accounts use this strategy to raise their followers. The core of the front stage is when the person has been favorable and gained many followers. When other people have liked them, the actors will retain their character to keep their amount of loyalty. 
The other finding was based on an interview with a vlogger that did not want to be published. The vlogger said that in the end, after having many followers and being celebgrams or Youtubers, the goal is not for making followers but being wealthy. Indeed, If the look of the Youtuber or celebgram is interesting, they may be asked to be an endorser for a product. In addition, with interesting videos and many views, many companies would also consider the account owners. As a result, the account owners can earn money from the ads that appeared on their videos. That explanation implies that dramaturgy may be performed not only for the sake of the number of followers but for earning financial advantage. In Kumit Project, apart from making videos that convey a certain message, the project also opened opportunities for anyone to hire them, Madkucil or Cimit, as endorsers. It is not surprising since even before the Kumit Project was established, they have been endorsers.

\section{CONCLUSION}

The research has shown that Kumit Project, through the actors, used impression management to create a certain impression on the audience when he was on the front stage. Their back stage were the actors, namely Madkucil and Cimit, which their lives were represented as the front stage, and the supporting crews. The dramaturgy they played was inspired by the actors on the back stage with additional background settings to amplify the dramatic effect.

In dramaturgy, social media became the front stage for the account owners to play the roles as intended, in addition to setting and dramatization. On the back stage, each actor went back to be himself, together with all unknown things to the followers. Consequently, what was presented on social media may not represent the real-life of the account owners. Impression management can be a way to show oneself on the front stage to attract the attention of the followers.

Erving Goffman's theory of dramaturgy is a complex study that is entangled with other related theories. The concept of dramaturgy in Goffman's work explained that dramaturgy is theatrical and theoretically is in the middle of symbolic interactionalism and phenomenology (Sukidin, 2002:103). The limit of the research is that the dramaturgical analysis only stopped at the concept of impression management. The research has not associated the finding with symbolic interactionalism and phenomenology.

\section{REFERENCES}

Atmoko, B. D. (2012). Instagram handbook. Jakarta: Media Kita.

Boyer, L., Brunner, B. R., Charles, T., \& Coleman, P. (2006). Managing impressions in a virtual environment: Is ethnic diversity a self-presentation strategy for colleges and universities?. Journal of Computer-Mediated Communication, 12(1), 136-154.

Bungin, Burhan. (2004). Metode Penelitian Kualitatif. Jakarta: Raja Grafindo Persada.

Creber, G dan Martin R. (2009). Digital Cultures: Understanding New Media. Berkshire: Open University Press.

Flew, Terry. (2002). New Media: an Introduction. Oxford: Oxford University Press.

Fuchs, C. (2014). Social Media a Critical Introduction. Los Angeles: SAGE Publications, Ltd

Goffman, Erving. (1956). The presentation of self in everyday life. Edinburgh: University of Edinburgh.

Jones, E. E., \& Pittman, T. S. (1982). Toward a general theory of strategic selfpresentation. Psychological perspectives on the self, 1(1), 231-262.

Langit, Marlinka S.P.S. (2017). Media Sosial Sebagai Panggung Presentasi Diri Mordelente. Skripsi. Tidak Diterbitkan. Fakultas Ilmu Sosial dan Ilmu Komunikasi Universitas Kristen Satya Wacana: Salatiga

Mayfield, A. (2008). What is social media.

Mulyana, Deddy. (2008). Ilmu Komunikasi : Suatu Pengantar. Bandung : PT. Remaja Rosda Karya

Mulyana, Deddy. (2003). Ilmu Komunikasi: Suatu Pengantar. Bandung: Remaja Rosdakarya

Nasrulla, Rulli. (2014). Teori dan Riset Media Siber (CyberMedia) cetakan pertama. Jakarta, Prenamedia Group 
Nasrulla, Rulli. (2015). Media Sosial Perspektif Komunikasi, Budaya dan Sosioteknologi. Bandung: Simbiosa Rekatama Media

Nurudin. (2012). Media Sosial Baru. Yogyakarta: Mata Padi Pressindo.

Nurudin. (2015). Media Sosial Sebagai Katarsis Mahasiswa. Komunikator, 7(2).

Poloma, M. Margaret. (2003). Sosiologi Kontemporer. Jakarta: Rajawali Grafindo Persada

Schlenker, B. R. (1980). Impression Management: The selft-concept, social Identity and Interpersonal Relation. Monterey. CA. Brooks/Cole

Utari, Prahastiwi. (2011). Media Sosial, New Media dan Gender dalam Pusaran Teori Komunikasi. Bab Buku Komunikasi 2.0: Teoritisasi dan Implikasi. Yogyakarta: Aspikom.

Widodo, Suko. (2010). Anatomi dan Perkembangan Teori Sosial. Malang: Aditya Media Publishing. 